\title{
16th Annual Lecture of the Geneva Association* The Financial Situation and Perspectives in Eastern Europe
}

\author{
by John S. Flemming**
}

\section{Introduction}

It is a great honour to have been invited to give this 16th Annual Lecture to your Association. I shall have great difficulty in matching the scholarship and rigour of the previous distinguished contributions - but the topic I was invited to address does not readily conform to those standards. My remarks today fall into four sections. The first is a sketch of the starting point confronting those embarking on the challenging task of transforming centrally planned economies into market economies. No sector is required to make bigger changes than the financial sector, and the reform of no sector is more crucial to the emergence of a healthy private sector. I shall also mention one or two parallels to the post war situation in Western Europe.

The second part of the lecture will spell out some of the changes required, while the third will focus on a number of practical difficulties associated both with an inheritance of non-performing loans and, even more problematically, the continued accrual of bad debts as enterprises with little prospect of ever trading profitability are, probably for good reasons, not put into liquidation.

I shall then address a number of issues relating to the privatisation of large stateowned enterprises and the fostering of grass roots enterprises in whose growth and prosperity lies the best long-term hope for the economies of Central and Eastern Europe. Finally I shall make some comments on the political economy of the region and the role of international institutions such as the EBRD.

\section{The financial challenge in Eastern Europe}

In the classic centrally planned economy, the financial sector played no role in the allocation of resources or the associated finance between competing ends - nor was it a channel for the transmission of monetary policy. The single banking structure combined, in reduced form, the rôles of both central and commercial banks. Money supply was controlled by ensuring that authorised expenditures, including payrolls and investment projects, matched planned outputs at the administered prices.

* Delivered at the Nineteenth General Assembly of the Geneva Association, Madrid, 11 and 12 May 1992.

** FBA, Chief Economist, European Bank for Reconstruction and Development. 
Limitations on internal convertibility meant that an enterprise could not necessarily spend its receipts, let alone any borrowings, as it chose - on the contrary it could only be spent in accordance with the agreed plan. The plan allocated what was planned to be produced, and its fulfilment meant a matching of supply and demand in both physical and financial terms. As the Chinese discovered, delegating any authority to enterprises reduced revenue from the appropriation of enterprise profits and led to a build-up of inflationary pressures as enterprise investment increased and central government expenditures failed to decline.

Bank branches were not established in order to bring local knowledge to bear in the assessment of project risk and management competence but simply to collect savings and to transmit funds. Neither of these called for much exertion: competition was non-existent and households could not even choose to buy more durable goods - for which a wait of years was common - though they did even then have to pay at least in part at the time of ordering. Households, which, with foreign entities, were almost alone in not being stateowned, rarely used bank accounts or cheques in payment. They made deposits in savings banks which offered low interest rates and no transmission services. In this, however, they did not differ greatly from the situation, for instance in Britain, where workers' deposits were largely with the Post Office, Savings Banks or Building Societies which have only offered money transmission services and cheque books in the last 20 years or so.

The clearing system for inter-enterprise payments involved no urgency in the matching of timing of settlement with transfer of title since all the parties concerned were organs of government. The payments system was not very different from the accounting or record keeping function and for this purpose promptness was not considered important. This has hampered the development of inter-enterprise contractual trade and is also an obstacle to inter-republican and international transactions. That fact that government was on both sides of most transactions also removed any counterparty or credit risk from banking operations.

The payments of wages in cash and the receipt by retailers of household cash expenditures were the only intersection between the cash and credit economies of households and enterprises otherwise confined to distinct "circuits". The banks could monitor and, if necessary, control payments of wages against central norms and could similarly transfer from enterprise to government accounts appropriate proportions of pay, sales revenue, or accounting profits. A weakening of control in these areas too has contributed to inflationary pressure by allowing bank credit to be used indirectly to meet household demands in the most recent period in the former Soviet Union. This has reinforced the effect of weaker revenue collections through the same channels.

Much more important, however, in explaining inflation in these economies in the last 10 years is the failure to develop significant non-monetary financing of the fiscal deficits which emerged in the USSR after 1985. A capital market allows governments to sell bonds whose liquidity is significantly less than that of bank deposits. While Hungary has had some success in this, the USSR made several attempts, all of which failed because the interest rates offered were too low or prospective purchasers feared that their claims would be dishonoured in a monetary reform.

For much of the time, of course, monetary financing did not lead directly to price increases because prices were controlled and inflation repressed. While central planning 
had long been characterised by a modest degree of persistent excess demand, the growing budget deficits of the later 1980 s converted this into a major problem as households accumulated cash they could only spend by diverting more energy from working to searching for goods or foreign exchange into which to convert it. Enterprises also sought materials and were reluctant to supply goods against local currency already in excess supply. This reluctance to supply, which applied particularly to supplying entities in another jurisdiction, represented regression towards barter, the inefficiency of which contributed to reduce effective output and further excess of demand over supply. Moreover barter transactions if not matched, as they need not be, by a financial transaction at a realistic nominal price, erode the basis for taxation and thus of revenue, aggravating the excess emission of money. In the case of international trade it had become normal to require exporters to surrender much of their hard currency earnings at an unfavourable exchange rate. This source of the currency needed to service government obligations to foreigners was also jeopardised by barter trade.

I have mentioned that savings deposits and the unsuccessfully marketed government bonds both bore low interest rates. Of course Marxist doctrine had something to do with this, but one needs also to consider the rôle of interest rates in a system of planning. While the design and selection of investment projects could have been based on estimated returns, finance and resources were allocated by planners not guided by market prices. The division of output between consumption and investment was similarly planned and households necessarily saved the excess of their money income over the cash value of consumer goods available at regulated prices.

A somewhat similar situation existed in Britain after World War II with extensive rationing of both consumer and investment goods - not ably building materials - and a need for permits for construction activity. In such a situation the main impact of interest rates is not on savings, investment or the allocation of resources but, where the government has accumulated substantial debt, on the budgetary cost of debt service. A secondary effect may be on the exchange rate, but, while this was significant in post war Britain, the exchange controls, absence of convertibility both for residents and non-residents, not to mention the artificiality of all of the prevailing multiple exchange rates, rendered this link also inoperative in most of Eastern Europe until very recently.

\section{Establishing a new financial system}

Partly for reasons I have mentioned relating to the tendency to restrict exports from any one republic or state to another member of the rouble area, partly for nationalistic reasons, and partly perhaps because the close link between fiscal deficits and monetary emissions would require tight central fiscal control of a continuing rouble zone, several of the successor states to the USSR are planning to introduce their own currencies. The Baltic states and the Ukraine are most advanced down this road. Such countries face the task of constructing a monetary and financial system virtually from scratch, but against a background of disrupted trading relations with other states and between enterprises, a transitional process in economic organisations, and weak public finances threatening hyper-inflation.

They have to establish a new currency and a new central bank and to devise a framework within which to conduct monetary and exchange rate policies. Although they have in principle agreed to do these things in ways that do not disadvantage other states, implemen- 
tation is a different question. New currencies ought to be issued in exchange for old rouble notes which should then be burnt or returned to Moscow. The conversion of bank deposit is more difficult and history provides many possible excuses for trying to spend the roubles, as does the threat of hard currency settlement at world prices for imports from Russia.

The IMF and national central banks are addressing many of these institution-building issues as well as related questions about the conduct of international, and especially transit, trade, and considering the merits of interstate payments arrangements that might economise on hard currency by extending limited mutual credits.

These are vital questions to which satisfactory answers must be found if trade between the successor states of the USSR is not to collapse as, or more, dramatically than that between the FSU and Central Europe, reducing the output and income of many states by as much as $50 \%$. I do not, however, intend to dwell on these issues but rather those shared more fully by the Central European economies which have rejected special payments arrangements and committed themselves to resident convertibility for current account purposes. These are countries that already have their own currencies, central banks, membership of IMF and BIS and established monetary policies.

On the collapse of communism they faced a major problem of stabilisation in the face of the cumulative effects of several years of repressed inflation which had given rise to the so called "monetary overhang", large in Poland, small in the Czech and Slovac Federal Republic. The liberalisation of prices without effectively demonetising much of the existing stock of money, was bound to convert repressed into a least temporarily open inflation if not hyper-inflation, as we have seen in Poland, Bulgaria, Romania, Albania and Russia, with annual inflation rates in the $100-500 \%$ range. The subsequent stabilisation depends upon establishing ex ante positive real interest rates, credible controls over credit or wage increases, or both, and in the context of a long overdue opening to international trade and competitiveness, a sensible exchange rate policy.

The difficulty of forecasting price changes, particularly in the early stages of liberalisation, means that high nominal interest rates have often been overtaken, in the event, by prices; but the willingness to raise interest rates to match inflation rates has certainly marked a very clear break from previous arrangements. Greater apparent success has been achieved by several countries, notably Poland in 1990/1, in holding its nominal exchange rates against the US $\$$ for over 12 months. This was made possible only by the fact that the zloty had initially been devalued to the full extent suggested by the previous black market rate despite thc argument that under the not quite completely controlled system the black market undervalues the domestic currency by almost as much as the official rate overvalues it.

Moreover, the commitment to maintain a fixed rate against the dollar did not sit comfortably with the aim of having domestic interest rates higher than the considerable inflation expected in the first stage of liberalisation and far above the inflation or interest rates of countries with hard currencies. The interest differentials implied by positive real interest rates suggested a rapid depreciation of the domestic currency despite the government's commitment to the contrary.

This contradiction has been resolved, without abandoning the use of the exchange rate as a nominal anchor, by the widespread adoption of "crawling peg" regimes - typically 
crawling against a basket of hard currencies. Under this arrangement a currency's rate of depreciation is limited, thus ruling out a resumption of hyper-inflation, and the government will typically commit itself to revising the rate of depreciation only towards zero. Apart from its closing of the circle of domestic interest rate, foreign interest rates and expected depreciation, the regime also answers the question "and what then?" that is inevitably raised by a commitment to hold a particular exchange rate for as long as is practicable. Without an answer to that question, temporary success in holding a particular rate may not build much confidence in a government's long-term anti-inflation policy.

In the short term this was bolstered by penal taxes on cxcessive wage increases, especially in the public sector. Nevertheless under the influence of their employees, many enterprises chose to pay at the margin 5-10 cents tax in order to pay one extra cent in net wages.

The growth of the money supply does not offer an effective nominal anchor wherc institutional change makes its velocity even more erratic than we have experienced in the West. Thus, control has tended to be on the banks' assets rather than their liabilities. They have been limited, by directive, as to how much credit they can extend. In some cases this has tended to go to old state-owned contacts at the expense of new small businesses, partly for old times' sake and partly to protect existing commitments. In Russia we have recently seen some relaxation of such controls in the hope of staving off imminent bankruptcies.

Stabilisation also requires that the budget cease to be a source of monetary expansion; either deficits must be reduced or they must be covered by non-monetary instruments. The time inevitably needed to develop capital market institutions means that the initial effort has been concentrated on the difficult task of deficit reduction. While cutting subsidies is a natural part of price liberalisation, and the proceeds of the liquidation of excessive stocks accrue to the government, there are several less favourable forces at work. Stabilisation itself is liable to depress economic activity and reduce profits accruing to the state as owner of enterprises. The collapse of trade in and around the FSU has converted this into deeper recession, which, together with elements of industrial restructuring, raises unemployment compensation for which falls on the state budget. Nevertheless deficits have been reduced from around $10 \%$ to under $5 \%$ of GDP in several cases.

Enterprise commercialisation and privatisation also threaten the budget as explicit tax rates are lower than those implicit in ownership, and many of the new private enterprises adopt a cavalier attitude to thcir liability to pay tax. The building of machinery, institutions and attitudes supporting tax compliance is a high priority - otherwise the competitive advantage of enterprises from which revenuc is not collccted will rapidly erode the tax base remaining in state-owned enterprises - many of which are in any case unprofitable at the prices and wages now ruling.

Apart from Hungary, the development of capital markets appears to be driven more by the process of privatisation than that of providing the government with bond finance. While sales of enterprises are largely to single owners, management groups or foreign companies, the Polish and CSFR mass privatisation schemes, involving vouchers and intermediaries, will give many people claims they will be anxious to trade. For macro-economic reasons governments may not be anxious to foster the liquidity of such claims immediately but a grey market at least is likely to emerge. Restrictions on the transferability of claims and the consequent slowing of the emergence of fully fledged stock exchanges are unlikely 
to retard economic development which has rarely depended on such markets for its primary finance. Moreover, very widespread holding of the shares in a particular enterprise is not conducive to the exercise of a proprietorial influence over management. Such influence is important in economies in transition for two reasons. In many cases the incumbent managers, who know their business, are as well qualified as any one to run it, but they obtained their position under the old regime and the transformation was not designed merely to remove the control of branch ministries and leave nomenclatura managers accountable to no one. The new owners must be seen to be in a position to monitor and replace managers. There is also a danger that management will be captured not by the owner of the business but by its employees, as happened with many state-owned enterprises as central control was relaxed, which is unlikely to stimulate the radical restructuring required, or the level of investment necessary to narrow the gap between Eastern and Western living standards.

I shall come later to the possible rôle of banks and other intermediaries in this connection. Here, however, I merely reiterate the need for the banks to upgrade their money transmission and clearing arrangements and to expand private and personal checking accounts and to recognise and manage the associated risks. This means assessing the creditworthiness of all their customers, monitoring their exposures and installing credit control systems - tasks calling for a massive training exercise both of loan officers and of banking supervisors. The first liberalisation of banking, particularly in the USSR, led to the establishment of banks as subsidiaries of industrial groups to which they then lent. In other cases, state banks were broken up along regional or sectoral lines. Thus, connected and concentrated lending of types disapproved by western bank regulators are very widespread in these countries.

In parallel with the supervision and regulation of banks, and stimulated by uncertainty as to the quality of bank management, thought is also being given to the introduction of deposit insurance, although it is no substitute for internal controls and external regulation. Indeed, the existence of explicit or implicit deposit insurance is a major part of the justification of official supervisory regulations - implying that deposit insurance can only safely be established where an adequate supervisory framework exists.

For this audience I should perhaps briefly mention other types of insurance and risk management which are very poorly developed apart from personal life and household risks. With state ownership all other risks were effectively pooled by the government. Privatisation will change this completely and even earlier commercialisation and hardening of budget constraints may formalise existing relationships and call for a much larger and more sophisticated insurance industry, drawing on foreign capital and expertise. The undercapitalisation of the existing insurance enterprises itself offers opportunities for foreign investment or participation in mainstream insurance business too.

\section{Coping with inherited debts}

A major financial problem of all transition economies is the network of non-performing loans on the books not only of banks but also of enterprises themselves which have in many cases extended credit to each other - partly through unhonoured cheques. To the extent that claims are interest-bearing, the interest is often rolled up into the outstanding principal pre-empting much of the new credit allowed to be extended. If such debts, which mean that banks' and other balance sheets are much weaker than they look, were all accumulated 
under the old regime, when subsidies often took the form of credits unlikely to be repaid, there would be a relatively simple solution. Many such debts should in any case have been substantially eroded by the excess of interim inflation over nominal interest rates.

What remains is owed by one state entity to another, whether a bank or other enterprise. Such debts can readily be cancelled without affecting the net indebtedness of the state or the reality of its budgetary position. The only constraint on the restructuring of such historic cross-claims is the need to respect those of households, largely in the form of savings bank deposits, and of foreigners.

One effect of cancelling the debts owed to the banks by some enterprises might be to leave the banks with too few assets to match their deposit liabilities to households. Any such shortfall could be made good by the government issuing bonds to the banks without affecting its underlying budgetary position.

Unfortunately the actual situation is not so simple. Opponents of such radical balance sheet cleansing argue that to forgive debts would set a bad precedent for the enforcement of hard budget constraints in future. If the relevant debts had all been accumulated under the old regime it would be easy to dismiss this "moral hazard" incentive argument - revolution and counter-revolution being sufficiently infrequent in the region. Unfortunately, however, many enterprises continue to accumulate debts they are unlikely ever to be able to repay. Thus, a prerequisite for balance sheet restructuring is that the incidence of unprofitable trading be reduced to a point at which normal standards for bankruptcy can be applied.

In the immediate aftermath of price and trade liberalisation, there is a very wide dispersion across enterprises in the ratio of value added at the new prices to wages at their old real revels (adjusted only for average price level changes). Indeed, many commentators assert that, in a significant number of cases, value added by the old operations would actually be negative at the new prices. If this is true of $10-20 \%$ of activity then, by continuity (at least if the relevant distribution is unimodal), it is hard to believe that there is not even more employment in enterprises that, while adding value - do not add enough to cover socially acceptable wages and are thus unprofitable to operate.

In this situation several questions arise: What is the appropriate criterion for invoking bankruptcy and liquidation procedures? Profitability or positive value added? To insist on profitability at freed prices might lead to unemployment rates of $25 \%$ or higher. Not only are these unlikely to be socially acceptable but they are economically inefficient if the unemployed receive benefits that are larger than the gap between the value added in their previous rôle and an acceptable wage. In this case keeping people in employment (albeit unprofitable) would reduce demands on the budget and almost certainly add more to output than to consumption thus increasing the resources available for investment in the profitable sectors.

How should they be kept in employment? By extending credit to unprofitable firms (as happens now)? or by an explicit but temporary employment subsidy? Or could an appropriate structure of temporary tariffs achieve the desired effect while actually generating revenue? The exploration of these alternatives and possible methods of making the temporariness of special measures credible, for instance by international agreement, would take us beyond the bounds of my present subject. Nevertheless it is clear that as long as unprofitable enterprises are allowed to run up debts they stand little chance of either servicing or repaying, there will remain serious problems for the financial sector. Discipline would be 
unduly weakened by debt write-offs: the lessons lenders have to learn will not, in the interim, apply: both the unprofitable enterprises and those lending to them will be virtually impossible to privatise. For all these reasons the nettle of unprofitable enterprises has to be grasped promptly and resolved one way or the other. It will be fascinating to see the result of recent Hungarian legislation which will trigger bankruptcy procedures that are already in place. Hungary, where price and trade reforms have been underway for many years, is probably better placed to implement this procedure at this point than is any other country undertaking the transition from plan to market.

\section{The path to privatisation}

The problems discussed in the last section related to state-owned enterprises. These should either give way to newly established and growing private enterprises or they should be transferred to private ownership by sale or other means. Considerable success has already been achieved by so called "small privatisation" - the auctioning (typically) of retail, service and craft businesses which, together with totally new ones, form the basis for the organic growth of private enterprise.

Where they have good growth prospects there is likely to be a need for finance and the organisation of a financial sector capable of ministering to their needs, and not directing all available credit to unprofitable state enterprises. The task is, however, difficult and not only because of the inexperience of existing bank employees in assessing the relevant business plans and their associated risks.

In every western country there are special agencies or policies to help small enterprises with partial guarantees, subsidised interest rates or consultancy services. Why is this done? The first reason is that there is a size cut-off below which conventional loans are difficult to arrange because there is an element of fixed cost in any loan relationship and the cost may actually be higher when the borrower is inexperienced and unfamiliar with business management.

To the extent that these costs are social costs there would seem to be no reason to modify the market cut-off. Intervention can be rationalised in either of two ways; that the reasons for the cut-off, though economically sound, are not socially acceptable and governments respond to political pressure to fill the gap. Alternatively one may argue that very small enterprises constitute the seed bed of capitalism and that there are economic and social externalities to their growth that warrant intervention especially in particular areas of social deprivation, for instance in inner cities or amongst ethnic minorities. In these latter cases, in particular, schemes are often designed to mobilise and supplement private charitable efforts involving such people as retired bank managers or accountants or similar people seconded from large organisations.

The problem with applying these arguments in economies in transition is that the skills concerned with drawing up business plans, with marketing and with finance are in extremely short supply throughout the economy. Where a talented and qualified individual exists should she be assigned to doubling the efficiency and growth rate of a mini-business or to raising efficiency by $1 \%$ and halving the rate of decline of an obsolete business a thousand times bigger? The only easy answer is that the constraint of the scarcity of such people should be shifted as fast as possible by suitable training programmes initially involving considerable foreign assistance. 
Experience in the Wcst also suggests encouraging emerging entrepreneurs to exchange ideas, experience and mutual support and encouraging largc enterprises to use small ones as suppliers and subcontractors - for instance by providing a suitable information exchange.

Large scale privatisation encounters other problems; I have already alluded to those relating to corporate governance - the need to reconcile wide dispersion of ownership with sufficient concentration to ensure effective discharge of proprietorial functions. This might be achieved by suitable intermediaries but they would have to be rather different from the institutional investors familiar in the West which are too passive, and possibly too numerous. What is required is a new animal, part mutual fund, part holding company, part venture capital fund and part realisation agency. Poland has gone some way down the road but even if such an animal could be brought into cxistence as a fund manager therc would remain the problem of who would negotiate the management contract on behalf of the numerous beneficiaries. Is this rôle sufficicntly remote from management that it could bc undertaken by government appointed trustees acting under appropriate legal guidelines?

Therc is also a problem about the number of such funds if they do not have totally dominant holdings but have some cross-holdings. The numbers required by the need to ensure competition in product markets become much greater than the countries following this route appear to recognise, while the demands of such funds on managerial skills make it unfeasible to match the numbers of more passive institutional investors in the West.

An alternative route is to seek the performance of the rôle of monitoring, and of necessary intervention in management, not from equity holders but from creditors such as lead banks (which might also have a modest equity stake). This German/Japanese model has much to commend it though here again the requirements for competition in the product market may have implications for the number of banks. We have also seen that the qualifications of existing bank management for the task are very questionable. Just as the special intermediary funds might need an infusion of foreign managerial skills so too might the banks if they were to perform this rôle.

\section{Conclusions}

What are the implications of the situations I have depicted? The connected problems are clearly daunting. Where should the vicious circle of financial weakness be broken into? This is not a question answered by the standard, though inconclusive literature on sequencing reforms. That concentrates on questions relating to trade and price liberalisation, stabilisation, privatisation and restructuring, monetary reform and currency convertibility. My focus today has been very much narrower.

Nevcrtheless I hope that my conclusions are clear. A healthy financial sector presupposes, and reinforces, a healthy commercial and industrial sector. Thus the first requirement is a macro-economic policy and approach to price and trade reform that ensure that initially nearly all enterprises that add value at world prices are also profitable at domestic prices. Only gradually can bankruptcy be made the virtually automatic consequence of failure to achieve profitability at free, world, prices.

In the meantime domestic financial institutions can lend to profitable enterprises provided that both parties have strong enough balance sheets. Restructuring the balance sheets of enterprises that are trading profitably is not a major problem. The uncertainties of transition suggest a bias towards equity finance, but some initial allocation of bank or bonded 
debt to industrial firms would accelerate the system's convergence towards its (stochastic) steady state.

To the extent that industrial enterprises can carry high quality bank debt the government need supply less government debt as a counterpart to deposits in banks' balance sheets. This represents the capitalisation of the net fiscal benefits of ensuring that sufficient industry can trade profitably.

Given the extent of industrial profitability the governments' fiscal problems are not improved by refusing to recapitalise insolvent banks. Depositors will presumably be paid both their principal and any interest due. The only question is whether the liability is recognised and capitalised - not whether it exists.

If industry is profitable enough, and banks are adequately capitalised, either or both could be privatised on a larger scale than is yet occurring. There is much to be said for a balanced programme of sales of financial and non-financial companies. It is unlikely to be satisfactory to have private industry totally dependent on state owned banks - or for private banks to have only state owned clients. What is less clear is how far in the course of a balanced programme transactions between public banks and private businesses, or vice versa, should be discouraged.

\section{Is such a programme in prospect?}

The countries of Eastern Europe have not been reluctant to undertake courageously radical reforms but relatively few of them have been seen to be carrying out structured strategies which depend, not only on perception and comprehension of the nature of the problem they face, but also on a government secure enough in its popular support and constitutional tenure to adopt a strategic approach.

Many radical policies have been presented as being likely to build popular support for reform. This is by no means self evident where the number of losers is large - even if a minority. Others urge that reform should start with things that make people better off and whet their appetite even if subsequent steps will be less rewarding and the expectations raised disappointed.

What we can say with confidence is that formulating a programme, orchestrating political support for it, and implementing it consistently, though responsively, is a major task for which international assistance is likely to prove invaluable if not indispensableassistance in analysis, formulation and, especially, implementation where foreign experience and expertise in the practicalities of financial arrangements can be communicated through joint ventures and financing arrangements. The inflow of foreign capital, and particularly direct investments in which risks are shared, also have a part to play.

In all of these aspects of the problems confronting the countries of Eastern Europe and of those encountered by Western enterprises seeking mutually beneficial relationships with them, the EBRD is concerned and anxious, within its resources and competence, to deploy its 50 members' 10 billion ecu capital subscriptions effectively and to use the technical assistance funds they and others provide as effectively as possible in cooperation with other international and regional institutions. 